BIOREMEDIATION OF CHEMICAL POLLUTANTS- CONTAMINATED WATER

\title{
A-BIODECOLORIZATION OF CRYSTAL VIOLET CONTAMINATED WATER BY Pseudomonas geniculata
}

Hauka, F. I. ${ }^{1}$; El. B. A. Belal ${ }^{2}$; M.A. A. Selim ${ }^{1}$ and A. I. Gad ${ }^{1}$

1- Agric. Micobiol. Dept., Fac. Of Agric. Mansoura Univ., Egypt.

2- Agric. Botany Dept., (Agric. Microbiol. branch), Fac. of Agric., Kafrelsheikh Univ., 33516, Kafr El-Sheikh, Egypt.

\begin{abstract}
Biodcolorization of crystal violet (C V) was investigated in aquatic system. C $V$ decolorizing bacterium (designated isolate AT 17) was isolated from effluent sample using enrichment technique by clear zone formation. Based on morphological, physiological and 16S rDNA, this bacterium was identified as Pseudomonas geniculata. It was capable of using $\mathrm{C} \mathrm{V}$ as a sole source of carbon. Nutrient agar medium inhibited $\mathrm{C} \mathrm{V}$ decolorization but mineral salt medium (MSM) increased C V decolorization. $\mathrm{C} \vee$ decolorizing by $P$. geniculata was found to be optimum at $\mathrm{pH} 7$ and $35^{\circ} \mathrm{C}$. Additional carbon sources (i.e., glucose) and nitrogen sources (i.e., peptone, yeast extract and beef extract) inhibited completely $\mathrm{C} V$ decolorization. On the ather hand, ammonium chloride and ammonium sulphate increased the $\mathrm{C} \mathrm{V}$ decolorization. Ammonium chloride was the best inorganic nitrogen source in $\mathrm{C} \mathrm{V}$ decolorization. Incubation period for 7 days was the optimum for $\mathrm{C} \vee$ decolorization. $P$. geniculata was able to decolorize $99 \%$ of $\mathrm{C} \mathrm{V}$ completely in liquid medium at $\mathrm{pH} 7$ and $35^{\circ} \mathrm{C}$ after 7 days comparing with uninoculated medium(control). There was no toxicity of detected $\mathrm{C} \mathrm{V}$ after 7 days of incubation with $P$. geniculata on Bacillus subtilis as microbial bioassay test. The dissipation of $\mathrm{C} \mathrm{V}$ was coinciding with increasing $P$. geniculata biomass in $\mathrm{C} \mathrm{V}$ contaminated water. This study has shown that P.geniculata $\mathrm{C} \mathrm{V}$ could be applied to remediate Chemical pollutants contaminated water.
\end{abstract}

Keywords: Crystal violet, decolorization, Microorganisms.

\section{INTRODUCTION}

Crystal violet falls in the class of triphenylmethane dyes which are commonly used in the clothing industry to dye wool, silk and cotton (Kim et al., 2005). It is well known as a biological stain, yet also possesses medicinal properties. It has been used in the treatment of pinworms and as a topical agent as well as being added to feed to prevent fungal growth (Azmi et al., 1998). The toxicity of effluent is because of the presence of dye or its degraded products which are mutagenic or carcinogenic. Therefore, the treatment of industrial effluents contaminated with dye becomes necessary prior to their final discharge to the environment. Various kinds of physicochemical methods are in use for the treatment of wastewater contaminated with dye. These methods are not environment friendly and cost-effective and hence become commercially unattractive (Nigam et al., 1996 and Azmi et al., 1998). 
Therefore, the purpose of this study was to isolate and characterize of the Crystal violet decolorizing microbial strain and its use in bioremediation of Crystal violet - contaminated water.

\section{Chemicals:}

\section{MATERIALS AND METHODS}

C V was donated by Agric. Microbiol. branch, Agric. Botany Dep., Fac. of Agric., Kafrelsheikh Univ., Egypt.

Microbial decolorization of the crystal violet:

Sampling and analysis of the effluent

The effluent samples (the sludge and the wastewater) were collected from the Station Exchange Aldoakhlah and Nasr Company for Textile orchard each of these areas Almehalla Alkobra. The samples were transported to the laboratory at $4^{\circ} \mathrm{C}$. Minimal Medium as mineral salt medium (MSM) and Nutrient agar medium were used through this study as described by (Brunner et al., 1980).

Isolation, screening and identification of dye decolorizing microorganisms from effluent.

Crystal violet decolorizing bacterium was isolated from effluent sample using enrichment technique use $100 \mathrm{ml}$ sterilized mineral salt liquid medium (MSL) in $500 \mathrm{ml}$ glass bottle containing $50 \mathrm{mg} / \mathrm{L}$ from C V as a sole source of carbon. Dilution series were prepared after the final time from enrichment culture in a glass test tube containing $9 \mathrm{ml} \mathrm{MSL}$ liquid medium up to $1: 10^{-6}$ and then $100 \mu \mathrm{l}$ of the third enrichment culture was transferred onto MSA plates containing crystal violet $(50 \mathrm{mg} / \mathrm{L})$ and spread evenly with sterilized glass beads and were incubated at $28^{\circ} \mathrm{C}$ for 7 days monitored for appearance of colonies by clear zone formation. (Belal, and El-Nady, 2013 and Shah et al., 2013)

Screening for Crystal violet decolorizing isolates by applying the clear zone test method.

Mineral salt agar medium (MSA) plates containing C V (50 mg /L) were inoculated with a loop full of bacterial culture from cultures of the strains. The increase in clear zone diameters developing on the MSA plates was followed up periodical ( 3 day and 7 day) and measured by slide gauge. Experiments were made in tri-plicates. At least three replicates experiments were performed with the unspotted plate as a control.

Identification:

The efficient selected Crystal violet (C V) degrading bacterial isolate was identified depending upon morphological and physiological characteristics as described by John (1984) and Bergy's manual of systematic bacteriology. (1984) as well as 16S rDNA (Boye et al., 1999). This technique was performed by sigma, Cairo, Egypt and GATC Company.

Effect of different culture conditions on decolorization of Crystal violet (C V) by P. geniculata strain AT 17

1-Media

MSA and NA were containing C V (50 mg /L) were inoculated a loop full of cultures from the strain and incubated at $28^{\circ} \mathrm{C}$ for 7 days. 
2-pH

The $\mathrm{pH}$ of the inoculated MSA was adjusted to $(4,5,7,8$ and 9$)$. The effect of $\mathrm{pH}$ on dye decolorization was checked after 7 days.

\section{3-Temperature}

The inoculated MSA was incubated at various temperatures $(20,30,35$ and $40^{\circ} \mathrm{C}$ ). The effect of temperature on dye decolorization was checked after 7 days.

\section{4-Nitrogen sources}

To study the effect of nitrogen sources on decolorization of $\mathrm{C} \mathrm{V,} \mathrm{MSA}$ with concentrations of nitrogen such as $\left(\mathrm{NH}_{4}\right)_{2} \mathrm{SO}_{4},\left(\mathrm{NH}_{4} \mathrm{Cl}\right)(0.5,1,1.5$ and $2 \%)$ and peptone $(5 \mathrm{~g} / \mathrm{L})$, Beef extract $(3 \mathrm{~g} / \mathrm{L})$ as well as yeast extract $(1 \mathrm{~g} / \mathrm{L})$ at $\mathrm{pH} 7$ and $35^{\circ} \mathrm{C}$.

\section{5-Incubation Time}

To determine the effect of incubation period, at the optimum culture conditions $\left(\mathrm{pH} 7\right.$ and $\left.35{ }^{\circ} \mathrm{C}\right)$ for different incubation period $(3,5,7,9$ and 11 days).

Decolorization of Crystal violet (C V) in MSL by P. geniculata strain AT 17

The bacterial cell suspension $\left(10^{7} \mathrm{cfu} / \mathrm{ml}\right)$ was then used to inoculate $100 \mathrm{ml} \mathrm{MSL}$ containing $(50 \mathrm{mg} / \mathrm{L})$ of the dye. The cultures were incubated at $35{ }^{\circ} \mathrm{C}, \mathrm{pH} 7$ and $150 \mathrm{rpm}$ for 7 days. The test principle is based on the decrease of the optical density of the dye during the dyes decolorization. The percentage of decolorization of the dye was determined photometrically using UV-vis pectrophotometer at $\mathrm{OD}_{590 \mathrm{~nm}}$ for $\mathrm{C} \mathrm{V}$. Control flasks of equal volume of MSL and dye without any microbial inoculation were incubated in parallel at all intervals to assess abiotic loss. During the experiment, samples were collected $(1 \mathrm{ml})$ periodically at $0,1,3,5$ and 7 day for estimation of viable cell count (cfu/ml) by using dilution series onto MSA containing of the dye and to determine the decolorization using UV-vis pectrophotometer. All the experiments were done in triplicates. The percentage of decolorization was calculated as by (Yatome et al., 1993).

\section{Toxicity test Crystal violet (C V) decolorizing products}

The bioassay of the remaining $C V$ toxicity was performed on the aqueous solutions after 7 days of incubation with P. geniculata strain AT 17. Bacillus subtilis, as gram positive bacterium was used as the test organism. The toxicity was determined by recording of inhibition zone in growth of $B$. subtilis comparing to control treatment (untreated). Plates were incubated at $35^{\circ} \mathrm{C}$ for 7 days.

\section{Statistical analysis}

Data were calculated as mean \pm standard deviation (SD) and analyzed using analysis of variance (ANOVA). Probability of 0.05 or less was considered significant. The statistical package Program was used for all chemometric calculations (Parshetti et al., 2011). 


\section{RESULTS AND DISCUSSION}

The most widely used screening method for Crystal violet (C V) decolorizing organisms is the so called "clear zone" method. The extracellular hydrolyzing enzymes secreted by the target organism decolorize the suspended dye in the agar medium into water soluble products thereby producing zones of clearance around the colony. The main advantage of this test is that it is generally fast, cheap and simple, and allows the simultaneous performance of a great number of parallel tests (Belal, 2003).

Isolation and screening of dye decolorizing microorganisms

From the microbial sources (textile effluent) a total of 19 morphologically different $\mathrm{C} \mathrm{V}$ decolorizing isolates were obtained.

Among 19 bacterial isolates, One bacterial isolate designated as AT 17 achieved higher C V decolorization (wider clear zone) comparing with the other isolates (Fig.1).

The results were compared with those obtained with noninoculated medium (controls).

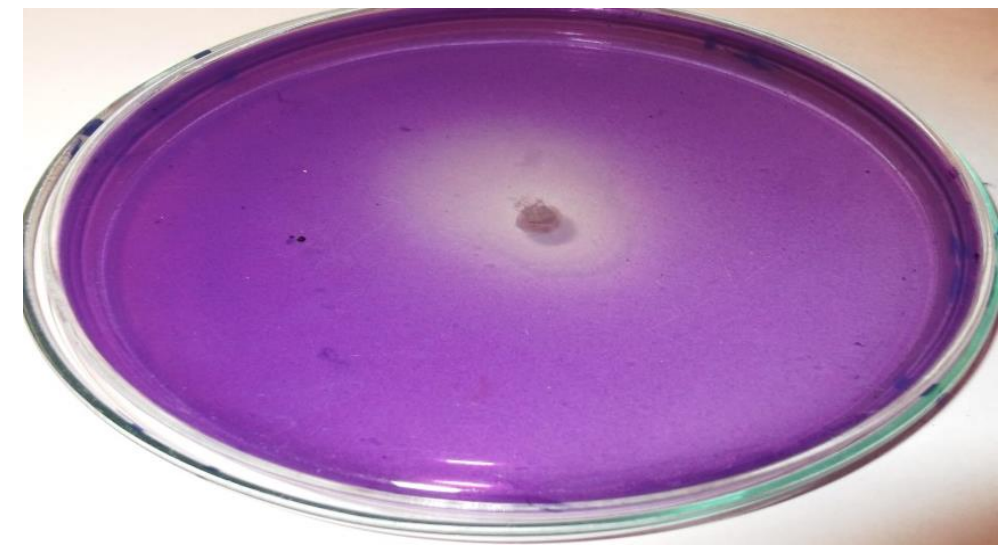

Fig. 1: Clear zone formation on MSA containing Crystal violet (C V) by The isolated bacterium.

Identification of the efficient of Crystal violet (C V) decolorizing isolate.

This bacterial isolate (AT 17) was identified according to morphological, physiological as well as using analysis of 16S rDNA (Boye et al., 1999). This efficient $C \mathrm{~V}$ decolorizing isolate (AT 17) was gram-negative, motile, short rods and oxidase positive. According to the $16 \mathrm{~S}$ rDNA analysis, the phylogenetic tree of the $\mathrm{C} \mathrm{V}$ decolorize bacterium isolate AT 17 and related bacterial species based on the 16S rDNA sequence is provided in Fig (2). It can be clearly seen that the Pseudomonas sp AT 17. as C V decolorize bacterium was included in the genus Pseudomonas and closely related to the 
species geniculata. It showed the highest sequence similarities with Pseudomonas geniculata strain ATCC 19374 (100\%) Figure (2).

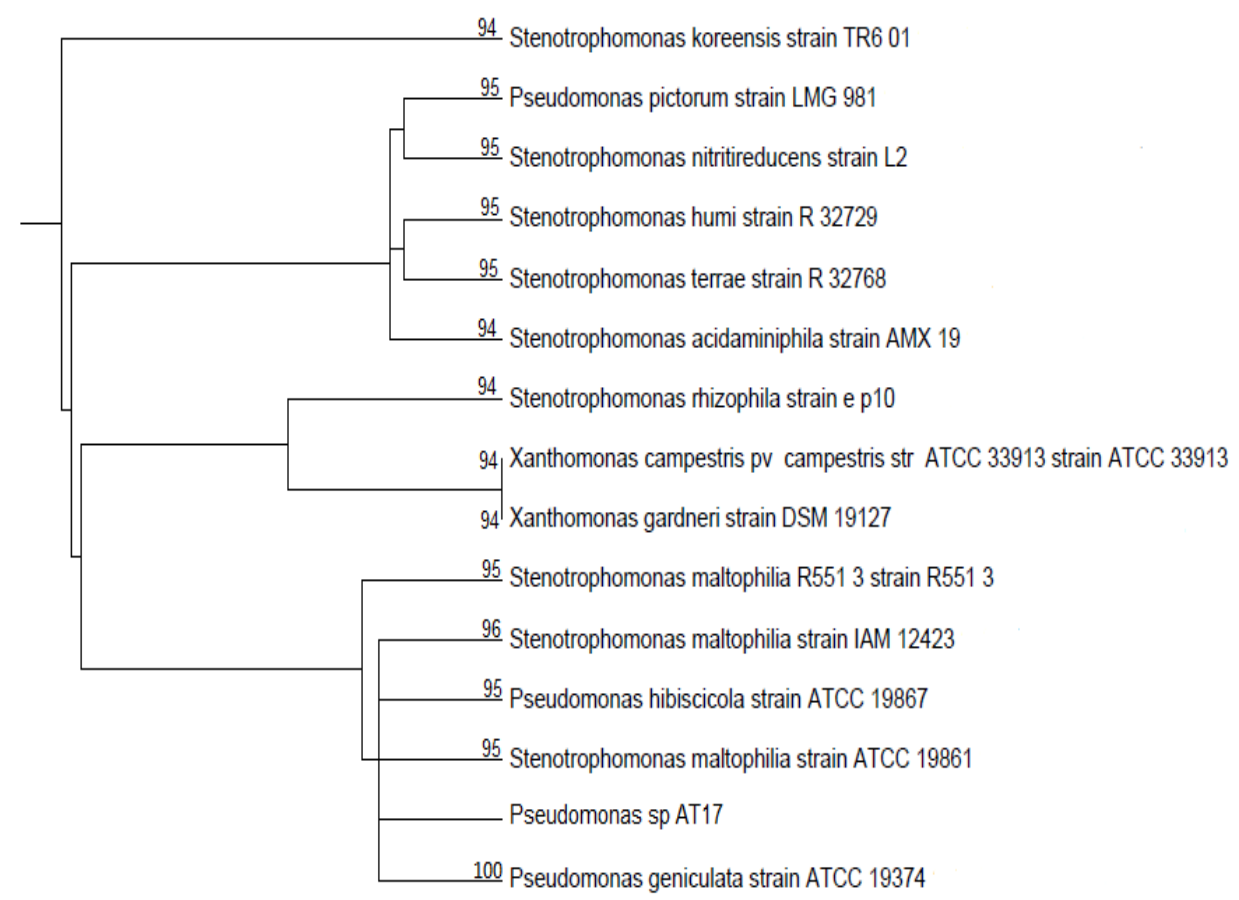

$\begin{array}{lllllll}0.012 & 0.010 & 0.008 & 0.006 & 0.004 & 0.002 & 0.000\end{array}$

Fig. (2): Phylogenetic dendrogram obtained by distance matrix analysis of $16 \mathrm{~S}$ rDNA sequences, showing the position of strain Pseudomonas geniculata AT 17 among phylogenetic neighbors. The scale bar indicates 0.02 substitutions per nucleotide position.

Effect of different Media on decolorization of Crystal violet (C V) by $P$. geniculata AT 17

MSA and Nutrient agar containing $C \vee(50 \mathrm{mg} / \mathrm{L})$ media were used to know the effect of the media on $\mathrm{C} V$ decolorization by clear zone formation. $P$. geniculata strain AT 17 formed only clear zone on MSA but it was observed that no clear zone was formed on nutrient agar medium containing $\mathrm{C} \mathrm{V}$ and this may be due to presence of nutrient components in nutrient agar medium suppressed $\mathrm{C} \vee$ decolorization enzymes which could be decolorize C V.

The results were compared with those obtained with noninoculated medium (control) incubated in the respective media. The noninoculated control showed no clear zone. MSA was selected for the further experiments. 


\section{Effect of different $\mathrm{pH}$ on decolorization of Crystal violet (C V) by $P$.} geniculata AT 17

The influence of $\mathrm{pH}$ on decolorization of $\mathrm{C} V$ in MSA with $P$. geniculata strain AT 17 by using clear zone formation is shown in Table (1). The highest $\mathrm{C} \mathrm{V}$ decolorization with strain was achieved at $\mathrm{pH} 7$ with wider clear zone formation followed by $\mathrm{PH} 8 \mathrm{C} \mathrm{V}$ was not decolorized by strain at $\mathrm{pH} 4$ and 5 (acidic $\mathrm{pH}$ ) as well as at $\mathrm{pH} 9$ (alkali $\mathrm{pH}$ ). This results are in agreement with Adedayo et al. (2004) who showed that Klebsiella pneumonia RS-13, which completely degraded Methyl Red in the $\mathrm{pH}$ range of $6-8$.

Table (1). Effect of different pH on decolorization of Crystal violet (C V) by P. geniculata strain AT 17

\begin{tabular}{|c|c|c|c|c|c|}
\hline \multirow[b]{2}{*}{ Strain } & \multicolumn{5}{|c|}{$\begin{array}{c}\text { Diameter of decolorization zone (clear) } \\
\text { zone }(\mathrm{mm}) \text { at different } \mathrm{pH}\end{array}$} \\
\hline & 4 & 5 & 7 & 8 & 9 \\
\hline Pseudomonas geniculata AT $17+\mathrm{C} \mathrm{V}$ & 0 & 0 & $37 \pm 0.05$ & $25.5 \pm 0.05$ & 0 \\
\hline Control (un-inoculated) & 0 & 0 & 0 & 0 & 0 \\
\hline
\end{tabular}

Effect of different Temperature on decolorization of Crystal violet (C V) by $P$. geniculata strain AT 17

The effect of different temperatures on decolorization of $C \mathrm{~V}$ is shown in Table (2). while the highest decolorization was achieved at $35^{\circ} \mathrm{C}$, (wider clear zone). The dye decolorization activity of the strain was found to decrease with increasing incubation temperature over $35^{\circ} \mathrm{C}$. and least decolorization at 30 , respectively. This can be explained that temperature can influence enzyme conformations which in turn effects catalytic activity (Staub and Denes, 1969).

Table (2): Effect of different Temperature on decolorization of Crystal violet (C V) by $P$. geniculata strain AT 17.

\begin{tabular}{|l|c|c|c|c|}
\hline \multirow{2}{*}{ Temperature } & \multicolumn{5}{|c|}{$\begin{array}{c}\text { Tiameter of decolorization zone (clear) zone (mm) } \\
\text { at different temperature }\left({ }^{\circ} \mathbf{C}\right)\end{array}$} \\
\cline { 2 - 5 } & 20 & 30 & 35 & 40 \\
\hline$P$. geniculata AT 17+ C V & 0 & $32 \pm 0.5$ & $43 \pm 0.5$ & $22.5 \pm 0.05$ \\
\hline Control (un-inoculated) & 0 & 0 & 0 & 0 \\
\hline
\end{tabular}

Effect of mineral nitrogen sources and components of nutrient broth medium on decolorization of Crystal violet (C V) by P. geniculata strain AT 17.

The effect of additional Nitrogen sources (such as 1\% ammonium sulphate and ammonium chloride) and components of nutrient medium (organic nitrogen) (peptone $5 \mathrm{gm} / \mathrm{L}$, beef extract $3 \mathrm{gm} / \mathrm{L}$ and yeast extract $1 \mathrm{gm} / \mathrm{L}$ ) is shown in Table (3). Mineral nitrogen sources (such as $1 \%$ ammonium sulphate and ammonium chloride) were the best in $\mathrm{C} \mathrm{V}$ decolorization (clear zone formation) by $P$. geniculata strain AT 17 . Decolorization was achieved with ammonium chloride more than ammonium sulphate. Components of nutrient broth medium suppressed the decolorization of $\mathrm{C} V$ by $P$. geniculata strain AT 17. 
Table (3). Effect of nitrogen sources on decolorization of Crystal violet (C V) by P. geniculata strain AT 17.

\begin{tabular}{|l|c|c|c|c|c|}
\hline \multirow{2}{*}{ Treatments } & \multicolumn{5}{|c|}{ Diameter of decolorization zone (clear zone) $(\mathbf{m m})$ on different } \\
nitrogen sources
\end{tabular}

Effect of different concentrations from ammonium sulphate and ammonium chloride on decolorization of Crystal violet (C V) by $P$. geniculata strain AT 17

Crystal violet $(\mathrm{C} \vee$ ) decolorization by $P$. geniculata strain AT 17 when grown on different concentrations $(0.5,1,1.5$ and $2 \%)$ of the best $\mathrm{N}$ source (ammonium sulphate and ammonium chloride) in presence of the best carbon source (C V) are presented in Tables (4). It was revealed that ammonium chloride at $1.5 \%$ was the optimum level for P. geniculata AT 17. Parshetti et al. (2011) who showed that Crystal Violet decolorization of $100 \%$ was observed with $0.1 \% \mathrm{NH} 4 \mathrm{Cl}$ within $5 \mathrm{hr}$.

Nigam et al. (1996) reported on how the highest decolorization was addition of inorganic nitrogen source (ammonium chloride or ammonium sulphate) but it decreased or inhibited completely addition organic nitrogen source (peptone or yeast extract). With fungal studies concerning dye degradation, additional nitrogen sources can either have a positive or adverse effect on decolorization. They proposed that nitrogen suppressed the enzymatic system and found that a nitrogen limiting environment stimulates enzyme production. Although it's clear that additional nitrogen reduces or inhibits decolorization.

Table (4): Effect of different concentration from ammonium chloride and ammonium sulphate on decolorization of Crystal violet by $P$. geniculata AT 17.

\begin{tabular}{|l|c|c|c|c|}
\hline \multirow{2}{*}{ Treatment } & \multicolumn{3}{c|}{$\begin{array}{c}\text { Diameter of decolorization (clear) zone (mm) at } \\
\text { different } \mathbf{N H}_{\mathbf{4}} \mathbf{C l} \text { or }\left(\mathbf{N H}_{4}\right)_{2} \mathbf{S O}_{4} \text { concentrations (\%) }\end{array}$} \\
\cline { 2 - 5 } & 0.5 & 0.1 & 1.5 & 2.0 \\
\hline \multicolumn{5}{|c|}{$\mathrm{NH}_{4} \mathrm{Cl}$} \\
\hline P.geniculata strain AT 17+ C V & $11 \pm 0.2$ & $32 \pm 0.17$ & $57 \pm 0.2$ & $20.5 \pm 0.15$ \\
\hline \multicolumn{5}{|c|}{$\left(\mathrm{NH}_{4}\right)_{2} \mathrm{SO}_{4}$} \\
\hline P.geniculata strain AT 17+ C V & $11 \pm 0.17$ & $11 \pm 0.17$ & $11 \pm 0.1$ & $12.5 \pm 0.05$ \\
\hline Control (un-inoculated) & 0 & 0 & 0 & 0 \\
\hline
\end{tabular}

Effect of different incubation period on decolorization of Crystal violet (C V) by P. geniculata strain AT 17 
Results in Tables(5) show that the effect of incubation time on $\mathrm{C} \mathrm{V}$ decolorization under optimum conditions $\left(\mathrm{pH} 7,35^{\circ} \mathrm{C}\right.$ and $\left.\mathrm{NH}_{4} \mathrm{Cl} 1.5 \%\right)$. The $\mathrm{C} \mathrm{V}$ decolorization (clear zone formation) increase with time dependent manner and highest $\mathrm{C} V$ decolorization was obtained after 7 days for growth of $P$. geniculata strain AT 17. The C V decolorization was similar at 7, 9 and 11 days after incubation time, respectively. Incubation period on decolorization of Crystal violet by Pseudomonas putida is 7 days (Chen et al., 2007).

Table (5): Effect of different incubation period on decolorization of $\mathrm{C} \mathrm{V}$ by P. geniculata AT 17.

\begin{tabular}{|l|c|c|c|c|c|}
\hline \multirow{3}{*}{ Treatments } & \multicolumn{5}{|c|}{ Diamatar of decolorization (clear) zone (mm) } \\
\cline { 2 - 6 } & $\mathbf{3}$ & $\mathbf{5}$ & $\mathbf{7}$ & $\mathbf{9}$ & $\mathbf{1 1}$ \\
\cline { 2 - 6 } & $\mathbf{3}$ & $52.5 \pm 0.08$ & $63 \pm 0.17$ & $63 \pm 0.5$ & $63 \pm 0.5$ \\
\hline P. geniculata + C V & $50 \pm 0.3$ & 0 & 0 & 0 & 0 \\
\hline Control (un-inoculated) & 0 & 0 &
\end{tabular}

Effect of decolorization of Crystal violet (C V) in MSL by $P$. geniculata strain AT 17 in aquatic system.

Additionally to the qualitative clear-zone tests, the degradation potential of $P$. geniculata strain AT 17 was characterized via percentage of decolorization determination of dyes in MSL. The decolorization potential obtained for $\mathrm{C} \mathrm{V}$ which obtained it with $P$. geniculata strain AT 17 at $35^{\circ} \mathrm{C}$ pH7 after 7 days. The results in Table (6) summarize the differences of decolorization for $\mathrm{C} \vee$ by $P$. geniculata strain AT 17 in aquatic system. In the present study, dyes decolorization was increased with increasing the incubation period in the medium amended with $P$. geniculata strain AT 17 in all cases. The application of $C \mathrm{~V}$ decolorizing strain increased the number of cultivable $\mathrm{C} \mathrm{V}$ - decolorizing cells in the the aquatic system during the 7 days of incubation (Table 6). The experimental results were compared with the noninoculated (control), which showed less decolorization of the dye due to a biotic stress.

Table (6). Decolorization of C V by $P$. geniculata strain AT 17 in aquatic system

\begin{tabular}{|c|c|c|c|c|c|c|}
\hline \multirow{3}{*}{$\overbrace{\text { Strain }}$ Treatments } & & \multicolumn{5}{|c|}{$\%$ Remaining of dyes and CFU/ml } \\
\hline & & \multicolumn{5}{|c|}{ C V } \\
\hline & & 0 day & 1 Day & 3 day & 5 day & 7 Day \\
\hline Control (un-inoculated) (C V) & $\%$ Remaining & $100 \pm 0$ & $100 \pm 0.0$ & $98 \pm 0.3$ & $96.9 \pm 0.2$ & $95.5 \pm 0.2$ \\
\hline \multirow[b]{2}{*}{ P. geniculata AT $17+\mathrm{C} \mathrm{V}$} & $\%$ Remaining & $100 \pm 0$ & $61.4 \pm 0.2$ & $47.7 \pm 0.2$ & $30 \pm 0.2$ & $1 \pm 0.2$ \\
\hline & $\mathrm{CFU} / \mathrm{ml}$ & $105^{\star} 10^{\prime}$ & $266 * 10^{\prime}$ & $247^{*} 10^{7}$ & $190^{*} 10^{\prime}$ & $105^{\star} 10^{\prime}$ \\
\hline
\end{tabular}

Chengalroyen (2011) found that, Bacterial strain Amycolatopsis orientalis SY6 was able to decolorize amido black, janus green and several triphenylmethane dyes effectively. This suggests that the same enzyme/s might be involved in the reduction of all these dyes. In general, it was noticed that bacteria capable of degrading $\mathrm{C} \mathrm{V}$ were also able to mineralize other triphenylmethane dyes such as malachite green, brilliant green and basic fuchsin. This allows for the speculation that either the enzymes responsible for triphenylmethane class degradation are more lenient in their substrate 
interactions or the dye structural differences are minor and hence easier to accommodate. Additionally, research done on P. pseudomallei found that decolorization of triphenylmethane dyes was not linked to the molecular weight or permeability of the compound through the membrane (Azmi et al., 1998).

\section{Toxicity evaluation:}

Fig. (3). Show $99 \%$ decolorizing of C V by $P$. geniculata strain AT 17 under the optimum conditions. Toxicity of the remaining $\mathrm{C} \mathrm{V}$ in the aqueous solution after 7 days of incubation with the tested microbial strain was evaluated using $B$. subtilis as a microbial bioassay test. $P$. geniculata strain AT 17 exhibited the highest decolorization for CV. The results showed that the supernatant of $\mathrm{C} \mathrm{V}$ after 7 days of incubation with $P$. geniculata AT 17 had no toxicity which could be detected against $B$. subtilis as a test organism. The obtained results were compared with control treatment ( $C \vee$ only) which revealed $100 \%$ of inhibition against $B$. subtilis under the same conditions (Fig. 4). This implies that the aqueous solution spiked with $C V$ was completely detoxified after 7 days of treatment with $P$. geniculata strain AT 17. It has been reported that these dyes inhibit cell growth by interfering with nucleic acid synthesis thus decreasing protein synthesis (Azmi et al., 1998). Yatome et al. (1993) were the first to elucidate the degradation of C V by Nocardia spp.

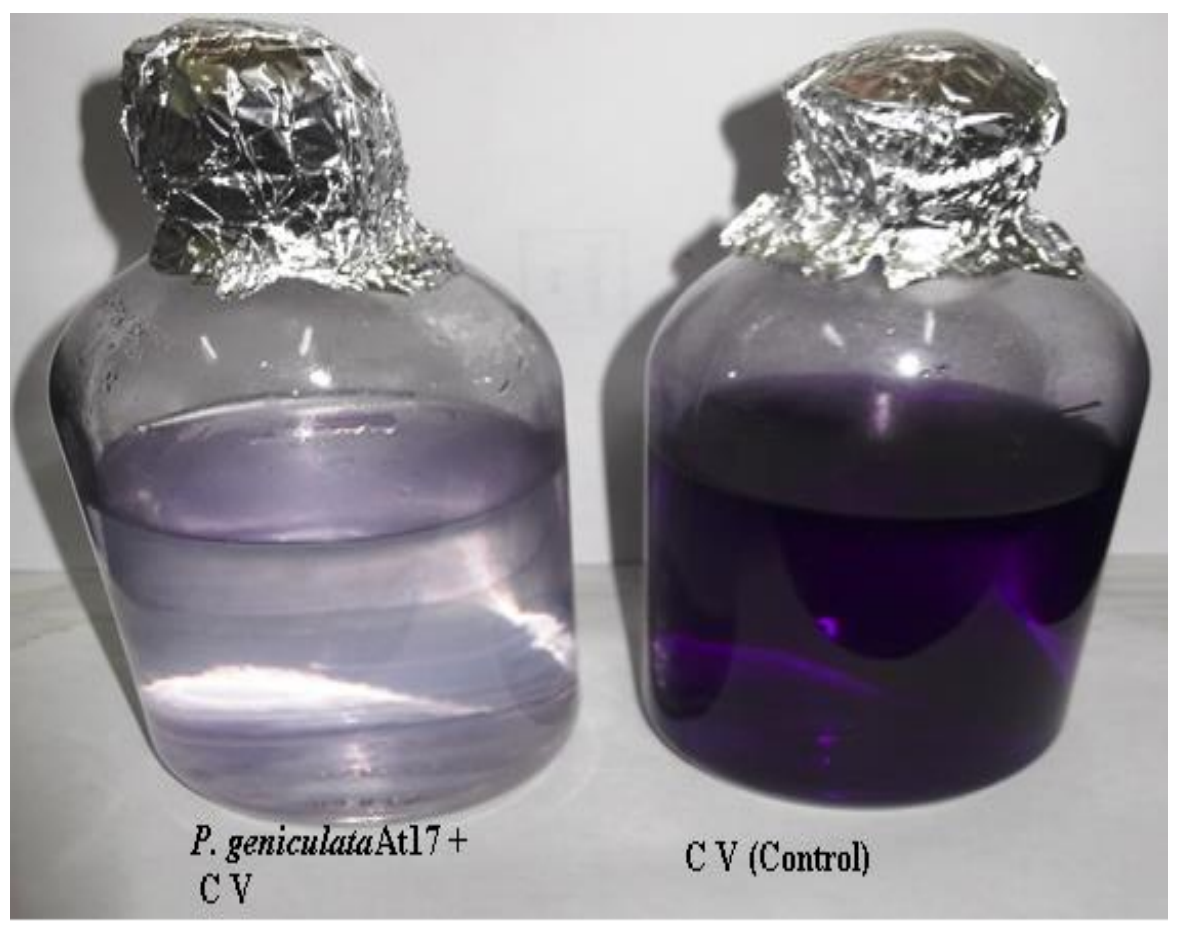

Fig. (3). Decolorization of C V by P. geniculata AT 17 in aquatic system. 


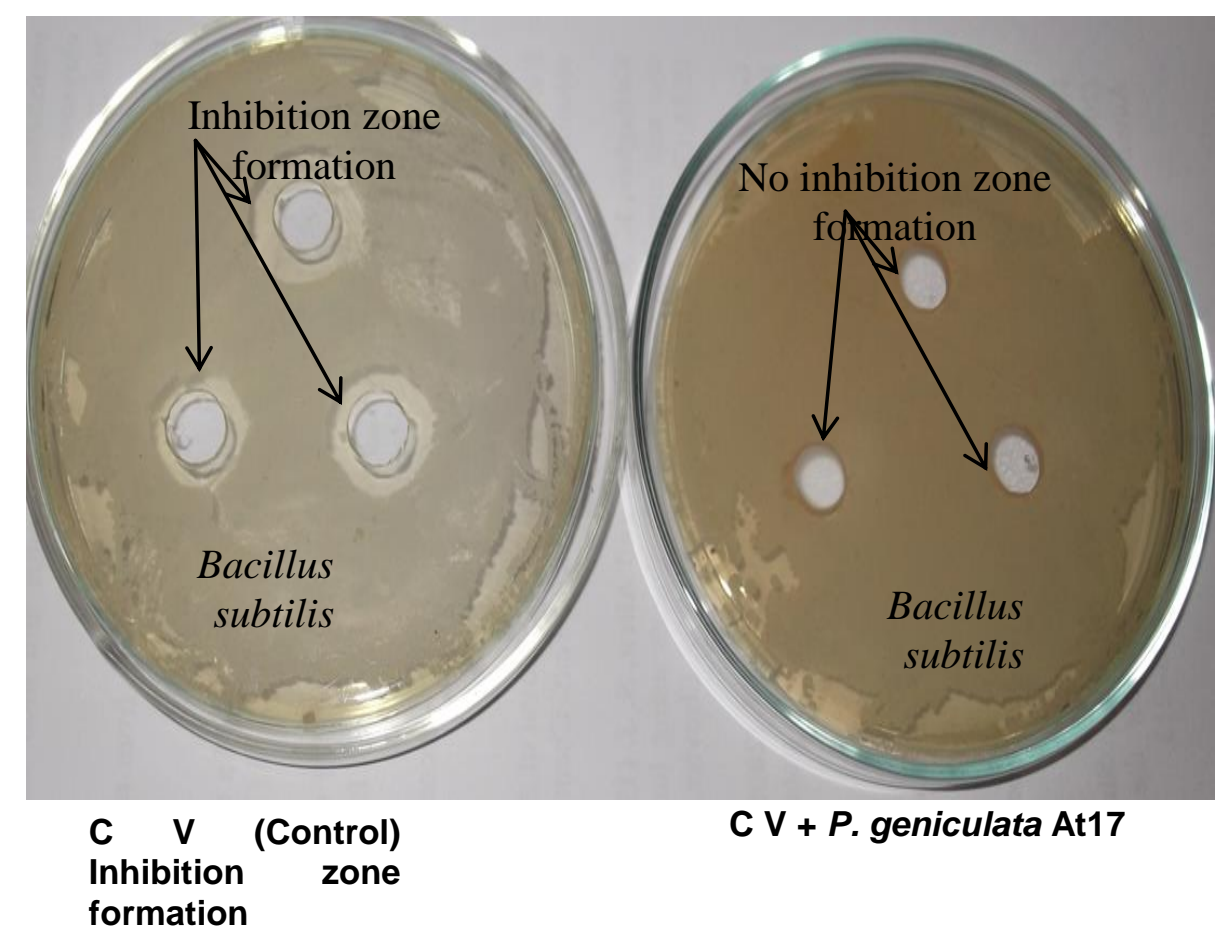

Fig. (4). Biodetoxfication of $\mathrm{C} V$ by $P$. geniculate AT 17 in aquatic system against $B$. subtilis as bioassay organism test on nutrient agar medium.

\section{REFERENCES}

Adedayo, O.; Javadpour, S.; Taylor, C.; Anderson, WA. and Moo-Young, M. (2004). Decolorization and detoxification of Methyl Red by aerobic bacteria from a wastewater treatment plant. World J. Microbiol. Biotechnol., (20):554-550.

Azmi, W.; Sani, R. K. and Banerjee, U.C. (1998). Biodegradation of triphenylmethane dyes, Enzymes and Microbial Technol., 22 (3): 185191

Belal, E. B. A. (2003). Investigation on the biodegradation of polyesters by isolated mesophilic microbes. Dissertation, Technical University Braunschweig, Germany.

Belal, B. E. and El-Nady, M. F. (2013). Bioremediation of pendimethalincontaminated soil. Afr. J. Microb. Res., 7(21): 2574-2588.

Bergy's manual of systematic bacteriology. (1984). Williams and Wilkins, Baltimore, USA. Vol. 1. Krieg, N. R. * (ed). Ordinary gram negative bacteria. Vol. 2. Sneath, P. h. A (ed.) Ordinary gram positive bacteria. 
Boye, K.; Høgdall, E. and Borre, M. (1999). Identification of bacteria using two degenerate $16 \mathrm{~s}$ rDNA sequencing primers. Microbiol Res. 154(1):23-29.

Brunner, W.; Staub, D. and Leisinger, T. (1980). Bacterial degradation of dichloromethane. Appl. Environ. Microbiol., 40: 950-958.

Chen, C. C.; Liao, H. J.; Cheng, C. Y.; Yen, C. Y. and Chung, Y. C. (2007). Biodegradation of crystal violet by Pseudomonas putida. Biotechnol. Letters., 29: 391-396.

Chengalroyen, M. D. (2011). Studies on triphenymethane, azo dye and latex rubber biodegradation by actinomycetes. University of Witwatersand South Africa., 139.

John, G. H. (1984). Ordinary gram negative bacteria. In: Bergy's Manual of Systematic Bacteriology, Baltimore. USA: Williams and Wilkins Press.

Kim, J. Y.; Lee, Y. M.; Jang, M. S.; Kang, D. W.; Kim, S. J.; Kim, C. H. and Lee, Y. C. (2005). Identification of genes required for decolorization of crystal violet in Citrobacter sp. MY-5, The J. of General and Appl. Microbiol., 51(3): 191-195.

Nigam, P.; Banat, I. M.; Singh, D. and Marchant, R. (1996). Microbial process for the decolorization of textile effluent containing azo, diazo and reactive dyes. Process Biochemistry, 31(5): 435-442.

Parshetti1, G. K.; Parshetti1, S. G.; Telke2, A. A.; Kalyani3, D. C.; Doong1, R. A. and Govindwar, S. P. (2011). Biodegradation of Crystal Violet by Agrobacterium radiobacter. J. of Environmental Sciences., 23(8): 1384-1393.

Shah, M. P.; Patel, K. A. and Nair, S. S. (2013). Microbiological removal of crystal violet dye by Bacillus subtilis ETL-2211. OA Biotechnol., $01 ; 2(2): 11$.

Staub, M. and Denes, G. (1969). Purification and properties of the 3-deoxy-Darabino-heptulosonate-7-phosphate syntase (phenylalanine sensitive) of Escherichia coli K12, Biochimica et Biophysica Acta, 178, 588-598.

Yatome, C.; Yamada, S.; Ogawa, T. and Matsui, M. (1993). Degradation of crystal violet by Nocardia corallina, Appl Microbiol and Biotechnol., 38: 565-569. 
المعالجة البيولوجية للملوثات الكيماوية فى المياه

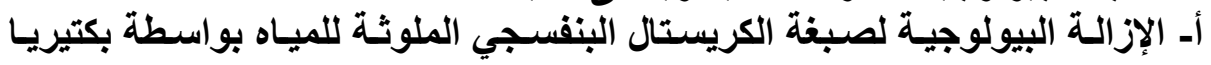

بسيدوموناس جينكيولاتا

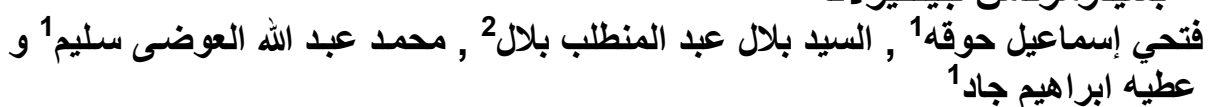

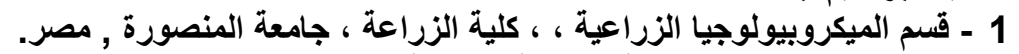

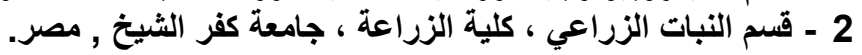

تم دراسة عملية إزالة اللون لصبغة الكريستال البنفجي الملوثة للماء من مصادر مختلفة مثل

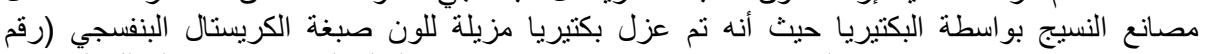

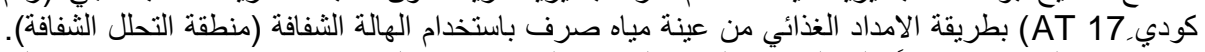

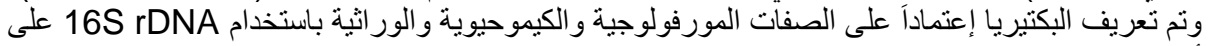

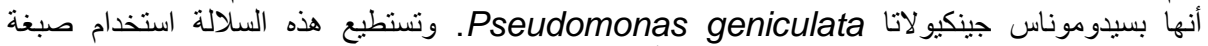

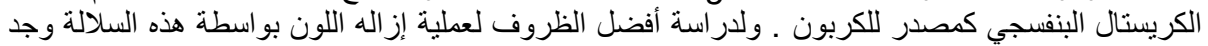

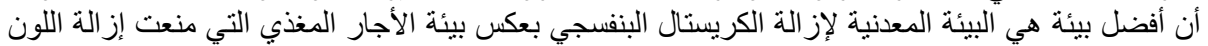

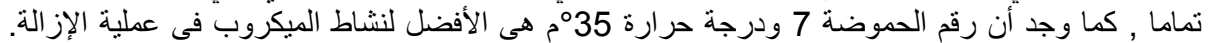

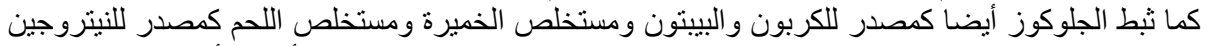

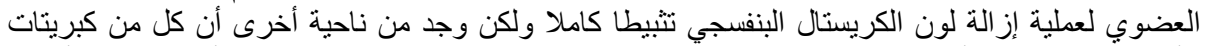

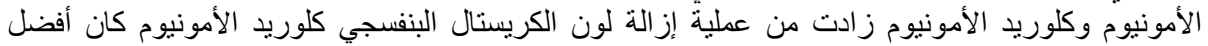

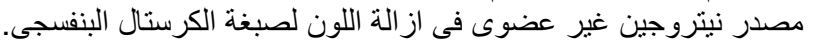

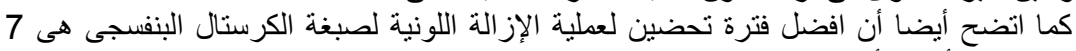

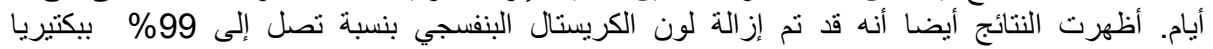

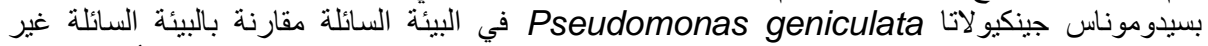

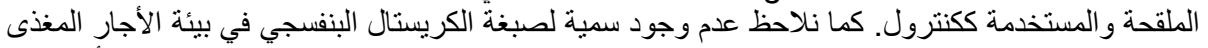

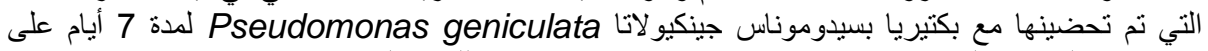

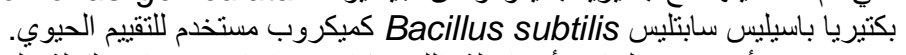
وأوضحت النتائج أن إزالة اللون كان متوافقالقا مع زيادة الكتلة الحيوية لبكتيريا بسيدوموناس

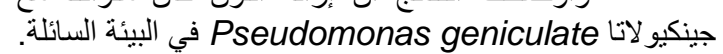

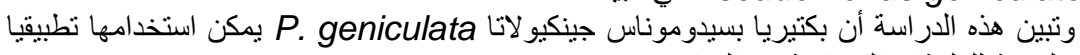
للمعالجة البيولوجية للملوثات الكيماوية فى المياه. 